\title{
Świętego Hieronima przedmowy do ksiąg biblijnych w Wulgacie - zagadnienia wstępne
}

\section{Wstęp}

Praca translatorska Sofroniusza Euzebiusza Hieronima trwała od roku 382 do jego śmierci. Jej poszczególne etapy i owoce, składające się na Wulgatę, oraz ich recepcja zostały już szczegółowo opisane ${ }^{2}$. Tematem pobocznym wobec wielkiego Hieronimowego dzieła biblijnego, ale przez to nie mniej interesującym, są przedmowy do łacińskich wersji ksiąg biblijnych. Warto jednak zaznaczyć, że prologi czy też przedmowy, jakie przez wieki umieszczano w Wulgacie, tylko częściowo pochodzą od św. Hieronima. W trzynastowiecznej Biblii Paryskiej znajdujemy na przykład sześćdziesiąt siedem wstępów do ksiąg biblijnych pochodzących m.in. z pism Izydora $\mathrm{z}$ Sewilli, Rabana Maura czy Piotra Lombarda ${ }^{3}$. Znajdujemy tam również krótkie marcjońskie wprowadzenia do listów św. Pawła, któ-

1 Ks. Michał Sołomieniuk, doktor nauk humanistycznych, dyrektor Archiwum Archidiecezjalnego w Gnieźnie; email: solomieniuk@gmail.com; ORCID: 0000-0002-3702-8096.

2 Ujęcie chronologiczne prac translatorskich na tle kolejnych etapów życia Hieronima, por. J. Steinmann, Hieronymus. Ausleger der Bibel. Weg und Werk eines Kirchenvaters, Leipzig [1973]. Ujęcie problematyczne, por. A. Canellis, Introduction, w: Jérôme, Préfaces aux livres de la Bible, red. A. Canellis, SCh 592, Paris 2017, s. 77-156; F. Van Liere, An introduction to the medieval Bible, New York 2014, s. 83-89. Na temat pracy nad samymi Ewangeliami, por. H. Houghton, The Latin New Testament: A Guide to its Early History, Texts, and Manuscripts, Oxford 2016, s. 31-35.

3 Por. Repertorium Biblicum Medii Aevi, t. 1, red. F. Stegmüller - K. Reinhardt, Madryt 1981. 
re najwidoczniej już przed Hieronimem funkcjonowały jako przedmowy Biblii łacińskiej ${ }^{4}$. Celem niniejszego przedłożenia jest zarysowanie problematyki związanej z tytułowymi wstępami: ustalenie ich listy, identyfikacja odbiorców, wskazanie w nich odniesień do filologii biblijnej i teologii, wreszcie ukazanie reminiscencji literatury i kultury klasycznej.

\section{Ustalenie listy przedmów autorstwa Hieronima}

Hieronim określa swe przedmowy kilkoma nazwami: praefatio, praefatiuncula, prologus, exordium, principium ${ }^{5}$. Stwierdza też, że dodaje przedmowy do każdej tłumaczonej księgi lub grupy ksiąg biblijnych: „Igitur et vos et unumquemque lectorem solita prafeatione commoneo, in principiis librorum eadem sempre adnectens [...]"6. Okazuje się jednak, że ustalenie listy przedmów jego autorstwa wymaga osobnych badań.

Z ostatniego stulecia możemy wymienić trzy dzieła, w których zestawiono same tylko Hieronimowe przedmowy do ksiąg biblijnych ${ }^{7}$. W chronologicznie najstarszym zestawieniu Friedricha Stummera mają one charakter aneksu do wykładów o Biblii łacińskiej ${ }^{8}$. W wydaniu krytycznym Wulgaty w recenzji Webera-Grysona (VWG) dwadzieścia przedmów Hieronimowych poprzedza odpowiednie księgi biblijne". Z kolei tom 592 serii Sources Chrétiennes (SCh 592) w całości został poświęcony przedmowom Hieronima do ksiąg biblijnych ${ }^{10}$. Różnice w tych trzech zestawieniach biorą się stąd, że VWG ani SCh 592 nie uwzględniają tekstów bez wątpienia Hieronimowych, ale będących albo osobnym utworem, albo cytatami z jego komentarzy bi-

4 Por. M.E. Schild, Abendländische Bibelvorreden bis zur Lutherbibel, Heidelberg 1970, s. 71-75.

5 Por. W. Stade, Hieronymus in prooemiis quid tractaverit et quos auctores quasque leges rhetoricas secutus sit, Rostochii 1925, s. 6.

6 Hieronymus, Prol. Iob (LXX) 2, SCh 592, s. 390. Skoro zatem niektóre księgi nie mają oryginalnego prologu, to albo on zaginął, albo Strydonita nie jest thumaczem ani nawet korektorem danej księgi.

7 Ponadto zestawienie przedmów znajduje się w: Clavis Patrum Latinorum, red. E. Dekkers, Turnhout 1995.

8 Por. F. Stummer, Einführung in die lateinische Bibel, Paderborn 1928, s. 222-262 (skrót: St.).

9 Por. Biblia sacra iuxta vulgatam versionem, red. R. Weber - R. Gryson, Stuttgart 2007 (skrót: VWG).

10 Por. Jérôme, Préfaces aux livres de la Bible, red. A. Canellis, SCh 592, Paris 2017. Tu aktualna, bogata bibliografia na s. 251-300. 
blijnych lub z dzieła $O$ znakomitych mężach. Przed poszczególnymi księgami umieścili je późniejsi redaktorzy. Osobnym dziełem jest używany jako wstęp do całej Biblii List 53: do kapłana Paulina [o studiowaniu Pisma] ${ }^{11}$, w którym autor, zwracając się do św. Paulina, biskupa Noli, pokrótce charakteryzuje poszczególne księgi biblijne (punkty 8-9). List ten pojawia się od IX wieku w większości rękopisów Wulgaty na samym jej początku ${ }^{12}$. $\mathrm{Z}$ kolei z dzieła $O$ znakomitych mężach wybierano rozdziały poświęcone św. Pawłowi (rozdz. 5), św. Jakubowi (rozdz. 2), św. Piotrowi (rozdz. 1) i św. Judzie (rozdz. 4). Żadne z tych trzech zestawień przedmów nie uwzględnia umieszczanych również jako wstępy do proroków mniejszych fragmentów Hieronimowych komentarzy do tychże proroków. Tylko redaktor z Sources Chrétiennes włącza do edycji prologów List Euzebiusza do Karpiana, który św. Hieronim przełożył z greki na łacinę i sam dodawał go do jako wstęp do tzw. kanonów Euzebiusza. Ta redaktor umieszcza natomiast w apendyksie, jako niehieronimowe, przedmowy, które występują u Webera-Grysona: do Księgi Syracha i do Listów św. Pawła ${ }^{13}$.

Zestawienie listy wstępów w Wulgacie edycji Webera-Grysona (VWG), u Stummera (St) i w Sources Chrétiennes (SCh 592), wraz z odnośnikiem do Repertorium Biblicum Medii Aevi, prezentuje się następująco:

\begin{tabular}{|c|c|c|c|c|c|c|c|}
\hline l.p. & $\begin{array}{c}\text { Do jakiej } \\
\text { księgi/ksiąg }\end{array}$ & incipit & explicit & VWG & St & $\begin{array}{l}\mathrm{SCh} \\
\mathbf{5 9 2} \\
\end{array}$ & RB \\
\hline 1. & [do całości] & $\begin{array}{l}\text { Frater Ambrosius } \\
\text { tua mihi munus- } \\
\text { cula }\end{array}$ & $\begin{array}{l}\text { qui se cogitat esse } \\
\text { moriturum }\end{array}$ & - & $\mathrm{x}$ & - & 284 \\
\hline 2. & Pentateuchus & $\begin{array}{c}\text { Desiderii mei } \\
\text { desidaratas }\end{array}$ & $\begin{array}{c}\text { eos transferre sermo- } \\
\text { nem. }\end{array}$ & $\mathrm{x}$ & $\mathrm{x}$ & $\mathrm{x}$ & 285 \\
\hline 3. & Iosue & $\begin{array}{c}\text { Tandem finita } \\
\text { Pentateucho Mosi }\end{array}$ & $\begin{array}{l}\text { debeamus aure tran- } \\
\text { sire. }\end{array}$ & $\mathrm{x}$ & $\mathrm{x}$ & $\mathrm{x}$ & 311 \\
\hline 4. & Regum $^{14}$ & $\begin{array}{c}\text { Viginti et duas } \\
\text { esse litteras apud } \\
\text { Hebraeos }\end{array}$ & silui a bonis. & $\mathrm{x}$ & $\mathrm{x}$ & $\mathrm{x}$ & 323 \\
\hline 5. & $\begin{array}{l}\text { Paralipome- } \\
\text { non (hebr.) }\end{array}$ & $\begin{array}{l}\text { Si Septuaginta } \\
\text { interpretum }\end{array}$ & $\begin{array}{l}\text { aures surdae sunt } \\
\text { ceterorum }\end{array}$ & $\mathrm{x}$ & $\mathrm{x}$ & $\mathrm{x}$ & 328 \\
\hline
\end{tabular}

11 Por. Hieronymus, Epistulae, pars 1, red. I. Hilberg, CSEL 54, Vindobonae Lipsiae 1910, s. 442-465, tł. J. Czuj - M. Ożóg, Hieronim ze Strydonu, Listy, t. 1, ŹMT 54, Kraków 2010, s. 25-36.

12 Por. Schild, Abendländische, s. 42.

13 Aline Canellis umieszcza także zestawienie odpowiednich oznaczeń z Clavis Patrum Latinorum. Por. Canellis, Introduction, s. 244-246.

14 Liber 1-2 Samuelis = 1-2 Regum, liber Malachim =1-2Krl czyli 3 i 4 Regum. 


\begin{tabular}{|c|c|c|c|c|c|c|c|}
\hline 6. & $\begin{array}{l}\text { Paralipome- } \\
\text { non (LXX) }\end{array}$ & $\begin{array}{l}\text { [Eusebius Hie- } \\
\text { ronumus Dom- } \\
\text { nioni] } \\
\text { Quomodo Grae- } \\
\text { corum historias }\end{array}$ & $\begin{array}{l}\text { Hebraeis voluminibus } \\
\text { non legatur. }\end{array}$ & - & $\mathrm{x}$ & $\mathrm{x}$ & 327 \\
\hline 7. & Ezrae & $\begin{array}{l}\text { Utrum difficilius } \\
\text { sit }\end{array}$ & $\begin{array}{l}\text { detractione et odio } \\
\text { deterrebor. }\end{array}$ & $\mathrm{x}$ & $\mathrm{x}$ & $\bar{x}$ & 330 \\
\hline 8. & Tobiae & \begin{tabular}{|l|} 
[Cromatio et \\
Heliodoro epi- \\
scopis] \\
Mirari non desino \\
\end{tabular} & estis dignati conplesse & $\mathrm{x}$ & $\mathrm{x}$ & $\mathrm{x}$ & 332 \\
\hline 9. & Iudith & $\begin{array}{l}\text { Apud Hebraeos } \\
\text { liber Iudith }\end{array}$ & $\begin{array}{c}\text { insuperabilem super- } \\
\text { aret. }\end{array}$ & $\mathrm{x}$ & $\mathrm{x}$ & $\mathrm{x}$ & 335 \\
\hline 10. & Hester & $\begin{array}{c}\text { Librum Hester } \\
\text { variis }\end{array}$ & $\begin{array}{c}\text { servi Christi esse non } \\
\text { possunt. }\end{array}$ & $\mathrm{x}$ & $\mathrm{x}$ & $\mathrm{x}$ & 341 \\
\hline 11. & Iob (heb.) & $\begin{array}{l}\text { Cogor per sin- } \\
\text { gulos }\end{array}$ & $\begin{array}{c}\text { quam malivolum } \\
\text { probet. }\end{array}$ & $\mathrm{x}$ & $\mathrm{x}$ & $\mathrm{x}$ & 344 \\
\hline 12. & $\begin{array}{l}\text { Iob (LXX } \\
\text { Hex.) }\end{array}$ & Si aut fiscellam & $\begin{array}{c}\text { Quam ex aliorum } \\
\text { negotio }\end{array}$ & - & $\mathrm{x}$ & $\mathrm{x}$ & 357 \\
\hline 13. & $\begin{array}{l}\text { In libro } \\
\text { Psalmorum } \\
(\mathrm{LXX})\end{array}$ & $\begin{array}{l}\text { Psalterium Ro- } \\
\text { mae dudum }\end{array}$ & $\begin{array}{l}\text { purissimo fonte po- } \\
\text { tare. }\end{array}$ & $\mathrm{x}$ & $\mathrm{x}$ & $\mathrm{x}$ & 430 \\
\hline 14. & $\begin{array}{l}\text { Inicipit alia } \\
\text { eiusdem prae- } \\
\text { fatio (heb.) }\end{array}$ & \begin{tabular}{|c|} 
[Eusebius Hie- \\
ronymus Sofronio \\
suo salutem.] \\
Scio quosdam \\
putare
\end{tabular} & $\begin{array}{l}\text { cupio et meminisse } \\
\text { mei. }\end{array}$ & $\mathrm{x}$ & - & $\mathrm{x}$ & 443 \\
\hline 15. & $\begin{array}{l}\text { In libris Salo- } \\
\text { monis (LXX) }\end{array}$ & $\begin{array}{c}\text { Tres libros Salo- } \\
\text { monis }\end{array}$ & $\begin{array}{l}\text { magis quam dubiis } \\
\text { commendare. }\end{array}$ & - & $\mathrm{x}$ & $\mathrm{x}$ & 455 \\
\hline 16. & $\begin{array}{l}\text { In libris Salo- } \\
\text { monis }^{2} \text { (heb.) }\end{array}$ & \begin{tabular}{|c|} 
[Cromatio et \\
Heliodoro episco- \\
pis Hieronymus.] \\
Iungat epistula \\
\end{tabular} & $\begin{array}{l}\text { suum saporem ser- } \\
\text { vaverint. }\end{array}$ & $\mathrm{x}$ & $\mathrm{x}$ & $\mathrm{x}$ & 457 \\
\hline 17. & $\begin{array}{l}\text { In libro Iesu } \\
\text { filii Sirach }\end{array}$ & $\begin{array}{l}\text { Multorum nobis } \\
\text { et magnorum }\end{array}$ & $\begin{array}{c}\text { proposuerunt vitam } \\
\text { agere. }\end{array}$ & $\mathrm{x}$ & - & $\mathrm{x}$ & 26 \\
\hline 18. & Isaiae & $\begin{array}{c}\text { Nemo cum } \\
\text { Prophetas vers- } \\
\text { ibus }\end{array}$ & $\begin{array}{l}\text { Ecclesiis eius diutius } \\
\text { insultarent. }\end{array}$ & $\mathrm{x}$ & $\mathrm{x}$ & $\mathrm{x}$ & 482 \\
\hline 19. & Hieremiae & $\begin{array}{c}\text { Hieremias } \\
\text { propheta, cui hic }\end{array}$ & $\begin{array}{c}\text { invidorum insaniam } \\
\text { provocare. }\end{array}$ & $\mathrm{x}$ & $\mathrm{x}$ & $\mathrm{x}$ & 487 \\
\hline
\end{tabular}




\begin{tabular}{|c|c|c|c|c|c|c|c|}
\hline 20. & Hiezechielis & $\begin{array}{c}\text { Hiezechiel } \\
\text { propheta cum } \\
\text { Ioachim } \\
\end{array}$ & 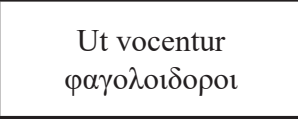 & $\mathrm{x}$ & $x^{15}$ & $\mathrm{x}$ & 492 \\
\hline 21. & Danihele & $\begin{array}{l}\text { Danihelem } \\
\text { prophetam iuxta } \\
\text { Septuaginta }\end{array}$ & $\begin{array}{c}\text { amore labuntur aut } \\
\text { odio. }\end{array}$ & $\mathrm{x}$ & $\mathrm{x}$ & $\mathrm{x}$ & 494 \\
\hline 22. & $\begin{array}{c}\text { Duodecim } \\
\text { prophetarum }\end{array}$ & $\begin{array}{l}\text { Non idem est } \\
\text { ordo }\end{array}$ & titulos prophetaverunt. & $\mathrm{x}$ & $\mathrm{x}$ & $\mathrm{x}$ & 500 \\
\hline 23. & In Evangelio & $\begin{array}{c}\text { Beato papae } \\
\text { Damaso Hie- } \\
\text { ronymus. Novum } \\
\text { opus }\end{array}$ & $\begin{array}{c}\text { memineris mei, papa } \\
\text { beatissime. }\end{array}$ & $\mathrm{x}$ & $x^{16}$ & $\mathrm{x}$ & 595 \\
\hline 24. & $\begin{array}{l}\text { In Epistulis } \\
\text { Pauli Ap. }\end{array}$ & $\begin{array}{c}\text { Primum quaeritur } \\
\text { quare }\end{array}$ & $\begin{array}{c}\text { et manentem substan- } \\
\text { tiam. }\end{array}$ & $\mathrm{x}$ & - & $\mathrm{x}$ & 670 \\
\hline 25. & jw. & $\begin{array}{l}\text { Paulus Apostolus, } \\
\text { qui ante Saulus }{ }^{17}\end{array}$ & $\begin{array}{c}\begin{array}{c}\text { sed ab omnibu explo- } \\
\text { ditur. }\end{array} \\
\end{array}$ & - & $\mathrm{x}$ & - & - \\
\hline 26. & Iacob & $\begin{array}{l}\text { Iacobus, qui } \\
\text { appellatur }^{18}\end{array}$ & falsa eorum opinio est. & - & $\mathrm{x}$ & - & - \\
\hline 27. & Petri & $\begin{array}{l}\text { Simon Petrus, } \\
\text { filius Ioannis }{ }^{19}\end{array}$ & $\begin{array}{c}\text { orbis veneratione } \\
\text { celebratur }\end{array}$ & - & $\mathrm{x}$ & - & - \\
\hline 28. & Iudae & $\begin{array}{l}\text { Iudas frater Ia- } \\
\text { cobi }^{20}\end{array}$ & $\begin{array}{l}\text { Sanctas Scripturas } \\
\text { computatur. }\end{array}$ & - & $\mathrm{x}$ & - & - \\
\hline 29. & $\begin{array}{l}\text { Eusebii epis- } \\
\text { tula ad Carpi- } \\
\text { anum }\end{array}$ & $\begin{array}{c}\text { Eusebius Carpia- } \\
\text { no fratri }\end{array}$ & $\begin{array}{l}\text { Similia dixisse rep- } \\
\text { peries. }\end{array}$ & - & - & $\mathrm{x}$ & - \\
\hline
\end{tabular}

Przedmiotem badań w niniejszym opracowaniu są przedmowy występujące SCh 592 za wyjątkiem Listu Euzebiusza do Karpiana. Wśród badaczy czasami występują wątpliwości w kwestii atrybucji przedmów, np. przedmowa do listów św. Pawła (w powyższej tabelce nr 24) jest przypisywana we wspominanym Repertorium Biblicum, z pewnym znakiem zapytania, Pelagiuszowi. Może to wiązać się z faktem, że pelagianie jako pierwsi używali systematycznie Hieronimowej wersji thumaczenia Biblii, szczególnie listów Pawłowych. Co więcej, sądzono, że to tłumaczenie jest

15 Explicit dłuższy: „[...] id est manducantes sannas”.

16 „Beatissimo”.

17 Hieronymus, De viris illustribus 5, w: Hieronymus - Gennadius, De viris inlustribus, red. C.A. Bernoulli, Freiburg im Breisgau - Lepzig 1895, s. 9-11, tł. W. Szołdrski, Św. Hieronim, O znakomitych mężach, w: Św. Hieronim, O znakomitych meżach, Eteria, Pielgrzymka do miejsc świętych, PSP 6, Warszawa 1970, s. 30-32.

18 Hieronymus, De viris illustribus 2, PSP 6, s. 6-8.

19 Hieronymus, De viris illustribus 1, PSP 6, s. 6.

20 Hieronymus, De viris illustribus 4, PSP 6, s. 9. 
ich właśnie dziełem ${ }^{21}$. Aline Canellis z kolei uznaje za niehieronimowe przedmowy do Księgi Syracha i do listów Pawłowych ${ }^{22}$. Trzeba od razu zaznaczyć, że Biblia w jednym woluminie pojawiła się dopiero w VI wieku, wcześniej krążyły osobno poszczególne księgi lub grupy ksiąg. Istniało też wiele przedmów różnych autorów, zatem i przedmowy dobierano wedle uznania, czasami przypisując Hieronimowi obce teksty. Działo się tak przez całe wieki, czego dowodem jest np. łacińska Biblia pochodzenia czeskiego z 1414 roku z Gniezna, w której wstęp do Dziejów Apostolskich jest przypisany św. Hieronimowi ${ }^{23}$.

\section{Dedykacje}

Wiele starożytnych dzieł było dedykowanych konkretnym osobom. Hieronim zachował ten zwyczaj, dzięki czemu poznajemy krąg odbiorców tłumaczeń ksiąg biblijnych. Poniższa tabela zestawia adresatów poszczególnych dedykacji.

Odbiorcy dedykacji:

\begin{tabular}{|c|c|c|}
\hline I.p. & księga/księgi biblijne & adresat dedykacji \\
\hline 1. & Pentateuchus & Dezyderiusz \\
\hline 2. & Iosue & [Pammachiusz vel Eustochium] \\
\hline 3. & Regum & Paula $i$ Eustochium \\
\hline 4. & Paralipomenon (Hebr.) & Domnio i Rogacjan \\
\hline 5. & Paralipomenon (LXX) & Domnio $i$ Rogacjan \\
\hline 6. & Ezrae & Chromacjusz bp i Heliodor bp \\
\hline 7. & Tobiae & Paula $i$ Eustochium \\
\hline 8. & Iudith & - \\
\hline 9. & Hester & Paula $i$ Eustochium \\
\hline 10. & Iob (Hebr.) & Paula $i$ Eustochium \\
\hline 11. & Iob (LXX Hex.) & Sofroniusz \\
\hline 12. & In libro Psalmorum (LXX) & - \\
\hline 13. & Inicipit alia eiusdem praefatio (Hebr.) & \\
\hline 14. & In libris Salomonis (LXX) & \\
\hline
\end{tabular}

21 M. Cimosa, Guida allo studio della Bibbia latina. Dalla Vetus Latina, alla Vulgata, alla Nova Vulgata, t. 1, Roma 2008, s. 47.

22 Canellis, Introduction, s. 247.

23 Gniezno, Archiwum Archidiecezjalne, BK Ms 142: Biblia sacra, k. 446: Lucas antiocensis; RB nr 637. 


\begin{tabular}{|c|c|c|}
\hline 15. & In libris Salomonis (Hebr.) & Chromacjusz bp i Heliodor bp \\
\hline 16. & In libro Iesu filii Sirach & - \\
\hline 17. & Isaiae & Paula $i$ Eustochium \\
\hline 18. & Hieremiae & - \\
\hline 19. & Hiezechielis & - \\
\hline 20. & Danihelem & Paula i Eustochium \\
\hline 21. & Duodecim prophetarum & Paula i Eustochium \\
\hline 22. & In Evangelio & Damazy pp \\
\hline 23. & In Epistulis Pauli Ap. & - \\
\hline
\end{tabular}

Piętnaście przedmów ma wyraźnych adresatów, którym jest dedykowane thumaczenie danej księgi lub grupy ksiąg, przy czym w połowie przypadków adresat pojawia się nie we wstępnym pozdrowieniu, a w dalszej części tekstu (oznaczono to kursywą) ${ }^{24}$. W jednym przypadku adresat jest domyślny na podstawie analizy treści, ale Strydonita nie zwraca się doń bezpośrednio, a jedynie o nim wspomina (oznaczono to nawiasem kwadratowym). Jedno tłumaczenie jest dedykowane papieżowi św. Damazemu (305-384), od którego prośby rozpoczęło się wielkie dzieło translatorskie Hieronima ${ }^{25}$. Biskupowi Akwilei św. Chromacjuszowi (ok. 345-406/407)26 są dedykowane trzy wstępy, w tym dwa łącznie z biskupem Heliodorem (ok. 350-ok. 407), pasterzem nadadriatyckiego Altinum ${ }^{27}$. Obydwaj byli przyjaciółmi Hieronima, przy czym Heliodor od dzieciństwa, pochodził bowiem ze Strydonu. Chromacjusz i Heliodor wspierali finansowo prace Hieronima ${ }^{28}$. Siedem przedmów zostało dedykowanych pobożnym niewiastom Pauli i Eustochium, matce wdowie i córce dziewicy, rzymskim arystokratkom o głębokiej wierze i wielkiej erudycji, kobietom, zaprzyjaźnionym między innymi z papieżem Damazym i wieloletnim współpracownicom

24 Również w rzymskiej literaturze klasycznej adresat dedykacji pojawia się w środku przedmowy. Por. Quintilianus, Instit., I Praef. 6: „Quod opus, Marcelle Vitori, tibi dicamus [...]", ed. L. Radermacher - V. Buchheit, Biblioteca Teubneriana, Lipsiae 1959, s. 4.

25 Papież ten wymieniał $\mathrm{z}$ Hieronimem listy, zachowane $\mathrm{w}$ spuściźnie epistolarnej tego ostatniego pod numerami 15, 16, 18A, 18B, 19, 20, 21, 36. Por. Eusebius Hieronimus, Epistulae, pars 1 (I-LXX), ed. I. Hilberg, CSEL 54, Vindobonae - Lipsiae 1910, s. 62-69, 73-142, 268-285, tł. J. Czuj - M. Ożóg, Hieronim ze Strydonu, Listy, t. 1, ŹMT 54, Kraków 2010, s. 40-41*, 44-81*, 150-158*.

26 Jest on też adresatem listu 7 wraz z Jowinem i Euzebiuszem.

27 Por. P. Zampa, I santi del Friuli, Pradamano 1930, s. 70-72. Heliodor jest adresatem listów 14 i 60 Hieronima.

28 Hieronymus, Prol. Salom. (hebr.), 1, SCh 592, s. 426. 
Hieronima w dziele krzewienia monastycyzmu ${ }^{29}$. Do kręgu chrześcijańskiej arystokracji rzymskiej należał również prokonsul św. Pammachiusz (zm. 410), wspomniany w jednej z przedmów ${ }^{30}$. Z kolei o Sofroniuszu wiemy jedynie, że był przyjacielem Hieronima, który przełożył wiele jego dzieł na język grecki ${ }^{31}$. Domnio i Rogacjan byli mnichami ${ }^{32}$.

Autor w większości przedmów zaznacza, że podjął się tłumaczenia danej księgi (grupy ksiąg) na zlecenie czy też prośbę konkretnych osób. Przedmowa jest zatem listem przewodnim, towarzyszącym prezentowi, jakim jest dla danej osoby zamówione lub uproszone thumaczenie. Przedmowy, które nie posiadają dedykacji, prawdopodobnie początkowo je posiadały, ale utraciły za sprawą późniejszych redaktorów ${ }^{33}$. Dedykacja bywa okazją do wyrażenia wielkiego szacunku albo silnych więzów przyjaźni autora $\mathrm{z}$ adresatami. Do Pauli i Eustochium zwraca się na przykład „unicum humilitatis et nobilitatis exemplar" ${ }^{34}$ lub stawia je na równi z ewangelicznymi kobietami - świadkami wiary ${ }^{35}$.

Drugim kręgiem osób, które na swój sposób pojawiają się w przedmowach, są przeciwnicy Hieronima ${ }^{36}$. Są to zarówno ludzie przyzwyczajeni do różnorodnych łacińskich wersji tłumaczeń ksiąg biblijnych i traktujący je bezkrytycznie (do nich Hieronim odnosi się z wyrozumiałością), jak i zazdrośnicy (tych natomiast traktuje bez pardonu). Autor nie wymienia ich nigdy z imienia. Wspomnienie o nich staje się jednak okazją do nieznającego miary ganienia tychże adwersarzy. Ten brak miary w połączeniu z argumentacją sofistyczną jest charakterystyczny dla Hieronima w ogóle ${ }^{37}$.

Tłumaczenie Ewangelii powstało na życzenie papieża Damazego, zatem miało być $\mathrm{w}$ założeniu upublicznione. $Z$ treści samych przedmów

29 Hieronim skierował do nich następujące listy: do Eustochium listy 22 i 31; do Pauli listy 30, 33, 39. Obu kobietom (a po śmierci Pauli tylko jej córce) Strydonita zadedykował też liczne komentarze biblijne.

30 Adresat listów Hieronima 48, 49, 57, 66; wraz z kuzynką Marcellą adresat listu 97; wraz z przyjacielem Oceanusem adresat listu 84.

31 Por. Hieronymus, De viris illustribus 134, PSP 6, s. 230-231. Sofroniusz thumaczył na grekę łacińskie tłumaczenie psalmów i proroków, które Hieronim poczynił z języka hebrajskiego.

32 Por. Canellis, Introduction, s. 191.

33 Różni badacze próbują widzieć adresata „,bezadresowych” przedmów w rzymiance Marcelli lub w biskupach Chromacjuszu, Heliodorze. Por. Canellis, Introduction, s. 195-196.

34 Hieronymus, Prol. Iob (LXX) 1, SCh 592, s. 388.

35 Hieronymus, Prol. Regum 4, SCh 592, s. 336.

36 Por. Schild, Abendlädische, s. 19-23.

37 Por. E. Norden, Die antike Kunstprosa, t. 2, wyd. 10, Leipzig 1995, s. 650-651. 
nie zawsze łatwo jest wywnioskować, które tłumaczenia Hieronim chciał upowszechniać, a które (przynajmniej w jego zamierzeniu) miały pozostać prywatnym darem. Być może te fragmenty, które zdają się wskazywać na drugie rozwiązanie, są tylko zabiegiem retorycznym. $Z$ historii literatury rzymskiej znamy przypadki wysyłania przez autora dzieła, zadedykowanego w przedmowie pewnej osobie, najpierw do wydawcy, ten zaś troszczył się o jego kopiowanie i rozpowszechnianie ${ }^{38}$. Istnieją przedmowy, w których Strydonita nie czyni zastrzeżeń co do upublicznienia owocu swej pracy translatorskiej, w innych pozwala na upublicznienie w ograniczonym zakresie, w jeszcze innych prosi adresata o zachowanie thumaczenia dla siebie. Ograniczenie w rozpowszechnianiu mogło mieć dwa powody: chęć ukrycia dzieła przed przeciwnikami Hieronima (tracili oni w ten sposób okazję do kolejnego ataku na tłumacza) i staranie o kontrolę pracy kopistów. W przedmowie do Księgi Ezdrasza czytamy:

Itaque obsecro vos, mi Domnion et Rogatione carissimi, ut privata lectione contenti, librum non efferatis in publicum, nec fastidiosis ingeratis cibos [...]. Si qui autem fratrum sunt $[\ldots]$ his tribuatis exemplar admonentes, ut Hebraea nomina, quorum grandis in hoc volumine copia est, distincte et per intervalla transcribant ${ }^{39}$.

Na chęć rozpowszechnienia dzieła wskazują z kolei pośrednio zwroty skierowane do nienazwanego z imienia czytelnika lub ogółu czytelników. Bez względu na to, czy zastrzeżenia były tylko zabiegiem retorycznym czy nie, brak jest świadectw na to, by przyjaciele Hieronima, będący jednocześnie sami autorami tekstów religijnych, cytowali Biblię w jego tłumaczeniu. Nigdy nie uczynił tego na przykład Chromacjusz.

\section{Merytoryczna zawartość przedmów}

Hieronim nie wykorzystywał przedmów, by przybliżyć czytelnikowi treść Biblii czy jej poszczególnych ksiąg. Nie zajmował się też szczególnie osobą i dziełem Jezusa Chrystusa oraz problemem wiary. Poświęcał natomiast wiele miejsca dociekaniom nad tekstem biblijnym, badał relacje między tekstem łacińskim, greckim, hebrajskim i aramejskim. Nade wszystko zaś bronił swojego tłumaczenia nazwanego wiele wieków póź-

38 Por. R. Gräfenhain, De more libros dedicandi apud scriptores Graecos et Romans obvio, Marpurgi Cattorum 1892, s. 47-52.

39 Hieronymus, Prol. Ezrae 1, SCh 592, s. 360. 
niej Wulgatą ${ }^{40}$. Można zatem powiedzieć, że głównym przedmiotem prologów są zagadnienia translatorskie i krytyka tekstualna.

Najstarszym prologiem jest prolog do Nowego Testamentu, dedykowany papieżowi Damazemu, który prosił Hieronima o rewizję tekstu łacińskiego (Vetus Latina) na podstawie tekstu greckiego. Pierwsze zdanie prologu (które cytuję we własnym tłumaczeniu) objaśnia i cel i powód prac Hieronima: „Zmuszasz mnie, bym stworzył nowe dzieło ze starego, abym nad egzemplarzami Pism, rozproszonymi po całym świecie, zasiadł jakoby jakowyś sędzia. A ponieważ różnią się one między sobą, mam rozstrzygnąć, które z nich odpowiadają greckiemu oryginałowi”41. Jeśli w przypadku pism Nowego Testamentu była jasność, że trzeba odnieść się do tekstu oryginalnego, to jasności tej Strydonita nie miał od razu w odniesieniu do pism Starego Testamentu. Widać to w zmieniającym się stosunku autora do Septuaginty ${ }^{42}$. Na wczesnym etapie prac translatorskich uważał on tekst grecki za podstawę przekładu. W przedmowie do ksiąg Paralipomenon według Septuaginty uznawał nawet natchnienie Septuaginty (w które wierzył już Filon Aleksandryjski), a powód zepsucia tekstu widział w przepisywaniu go z niepoprawionych egzemplarzy ${ }^{43}$. Uważał, że dodatki, jakie twórcy Septuaginty dołożyli do tekstu hebrajskiego, wynikają albo z „decoris gratia” (chęci upiększania), albo z ,auctoritas” Ducha Świętego ${ }^{44}$. Na dalszym etapie prac, kiedy ponownie tłumaczył z hebrajskiego księgi, już raz poprawione według Septuaginty, uważał obie wersje tłumaczeń za przydatne, a o swoim nowym dziele mówił: „nie w ten sposób tworzymy rzeczy nowe, by zniszczyć stare" "45. Ów dalszy etap prac (translacje z hebrajskiego na łacinę) rozpoczął się około $390 \mathrm{roku}^{46}$. Od tego czasu Hieronim nie tylko ograniczył się do wyboru tekstu hebrajskiego jako podstawy przekładu Starego Testamentu, ale też uznał za kanoniczne jedynie księgi znane w he-

40 Schild, Abendländische, s. 39, 41.

41 Hieronymus, Prol. Evang. 1, SCh 592, s. 470: „Novum opus facere me cogis ex veteri, ut post exemplaria Scripturarum toto orbe dispersa quasi quidam arbiter sedeam, et quia inter se variant, quae sint illa, quae cum Graeca consentiant veritate decernam" (tł. własne).

$42 \mathrm{Na}$ temat pojęcia i zakresu tej greckiej wersji ST, zwanej Septuagintą, por. M. Majewski, Jak przekłady zmieniają Biblię. O tłumaczeniu Pisma Świętego raz jeszcze, Kraków 2019, s. 20-22. W tej książce, na stronach 203-214, znajduje się obszerna bibliografia, dotycząca problematyki translatorskiej.

43 Por. Hieronymus, Prol. Paralip. (LXX) 1, SCh 592, s. 342.

44 Por. Hieronymus, Prol. Paralip. (LXX) 2, SCh 592, s. 346.

45 Hieronymus, Prol. Salom. (hebr.): ,neque enim sic nova condimus ut vetera destruamus", SCh 592, s. 430.

46 Por. Steinmann, Hieronymus, s. 181; Canellis, Introduction, s. 93. 
brajskim, palestyńskim kanonie biblijnym. Co więcej, według tekstu hebrajskiego porządkował kolejność poszczególnych fragmentów ksiąg. W krótkiej przedmowie do Księgi Jeremiasza Hieronim pisze: „porządek wizji, który u Greków i Latynów jest całkowicie pomieszany, przywróciliśmy do stanu pierwotnego. Opuściliśmy Księgę Barucha, jego [Jeremiasza] sekretarza, której Hebrajczycy ani nie czytują, ani jej nie mają, i oczekujemy za to wszystko złorzeczeń od zazdrośników" ${ }^{47}$. Ostatecznie w prologu do Ksiąg Królewskich wyraził swe przekonanie, że kanon hebrajski stanowi zarówno podstawę przekładu, jak i kryterium prawdziwości (natchnienia) poszczególnych ksiąg Starego Testamentu ${ }^{48}$. W ten sposób Hieronim wyłączył z Biblii całą grupę ksiąg jako apokryfy. Te mianowicie, które nie zostały napisane w oryginale po hebrajsku, ,cokolwiek jest poza tym, należy to zaliczyć do apokryfów"49. Kryterium wyłączenia grupy ksiąg było bardzo arbitralne (liczba liter alfabetu hebrajskiego = liczba ksiąg) i sam Strydonita ściśle się go nie trzymał, a wyłączone księgi wróciły trwale do Biblii, gdy tworzono Wulgatę. Pomimo to stanowisko Hieronima, kopiowane przez wieki razem z całym prologiem, zwanym przez niego samego „prologus galeatus”, wpłynęło na negatywną ocenę ksiąg deuterokanonicznych u Lutra i innych reformatorów. Jednym z powodów całkowitego zwrotu ku tekstowi hebrajskiemu była chęć dania merytorycznego „odporu” Żydom. Na końcu przedmowy do Księgi Izajasza Hieronim napisał: „,[Chrystus] wie, że napociłem się przy nauce obcego języka po to, by Żydzi już dłużej nie szydzili z Jego Kościołów, zarzucając im fałszywość Pisma Świętego" "50. Pisarz nie wyjaśnił jednak w żadnej przedmowie, czemu uznał nie tylko język hebrajski za podstawę przekładu, ale i kanon hebrajski za obowiązujący. Autor nie zauważa również nigdzie problemu krytyki samego tekstu hebrajskiego krążącego W różniących się od siebie wersjach. Nie był też konsekwentny w ograniczaniu się do tekstu hebrajskiego, gdyż tłumaczył Księgi Daniela, Judyty i Tobiasza $z$ chaldejskiego (aramejskiego) ${ }^{51}$. Innym ważnym argumentem

$47,[. .$.$] ordinem visionum, qui apud Graecos et Latinos omnino confusus est, ad pristi-$ nam fidem correximus. Librum autem Baruch, notarii eius, qui apud Hebraeos nec legitur nec habetur, praetermisimus, pro his omnibus maledicta ab aemulis praestolantes", Hieronymus, Prol. Hier. SCh 592, s. 440, 442. Osobną kwestią jest to, że Hieronim nie znał tych hebrajskich manuskryptów, które zawierają tekst Księgi Jeremiasza, zbliżony do Septuaginty.

48 Por. Hieronymus, Prol. Regum 1, SCh 592, s. 326.

49 Hieronymus, Prol. Regum 2, SCh 592, s. 332: „Quicquid extra hos est, inter apocrypha seponendum".

50 Hieronymus, Prol. Esaia 5, SCh 592, s. 436: ,[... ] qui scit me ob hoc in peregrinae linguae eruditione sudasse, ne Iudaei de falsitate Scripturarum Ecclesiis eius diutius insultarent”.

51 Por. Schild, Abendländische, s. 29-30. 
za thumaczeniem prosto z hebrajskiego był argument teologiczny: w Starym Testamencie znajdują się proroctwa, które jeszcze się nie spełniły za czasów Siedemdziesięciu (czyli przed Chrystusem), i ci dawni tłumacze ich nie rozumieli. Brak zrozumienia wpłynął zaś na błędne tłumaczenie z hebrajskiego na grekę. W pełni rozumieją dawne proroctwa dopiero chrześcijanie i przy tłumaczeniu ksiąg starotestamentalnych biorą pod uwagę właśnie już spełnione proroctwa. W przedmowie do Pięcioksięgu Hieronim tak się wyraził: „to, co lepiej rozumiemy, lepiej też wypowiadamy”52. W przedmowie do Pięcioksięgu, do Księgi Jozuego i do Ksiąg Kronik autor przytacza inny argument: w Nowym Testamencie znajdują się cytaty ze Starego Testamentu, które odpowiadają wyłącznie tekstowi hebrajskiemu ${ }^{53}$. Akurat ten argument nie w pełni odpowiada prawdzie, tj. część cytatów, przytoczonych w przedmowie do Pięcioksięgu i do Paralipomenon, znajduje się w Septuagincie, inne są trudne do zidentyfikowania nawet w Biblii Hebrajskiej.

Inny, ciekawy wątek pojawiający się w przedmowach to ocena literacka ksiąg (pisarzy) biblijnych. Dowodzi to faktu, że Hieronim podchodził do tekstu biblijnego również jako do tekstu literackiego ${ }^{54}$. Strydonita wysoko cenił pod tym względem Księgę Izajasza, podkreślając elegancję stylu proroka, której nie można oddać w tłumaczeniu:

Ac primum de Esaia sciendum quod in sermone suo dissertus sit, quippe qui vir nobilis et urbanae elegantiae nec habens quicquam in eloquio rusticitatis admixtum. Unde accidit ut prae ceteris florem sermonis eius translatio non potuerit conservare ${ }^{55}$.

Równie wysoko Hieronim cenił Księgę Ozeasza, niżej natomiast Księgę Jeremiasza, która jego zdaniem jest „,sermone [...] rusticior”56. Styl Księgi Ezechiela natomiast mnich z Betlejem uważał za umiarkowanie dobry: „Sermo eius non satis disertus nec admodum rusticus est, sed ex utroque medie temperatus" $" 57$.

52 Hieronymus, Prol. Pentat. SCh 592, s. 310: „[...] quod melius intellegimus, melius et proferimus",

53 Por. Prol. Pentat. 2, SCh 592, s. 304; Prol. Iosue 2, SCh 592, s. 318; Prol. Paralip. (hebr.) 3, SCh 592, s. 352.

54 C. Brown-Tkacz, Labor tam utilis. The creation of the Vulgate, „Vigiliae Christianae" 50 (1996) s. 43-44.

55 Hieronymus, Prol. Esaia 2, SCh 592 s. 434.

56 Hieronymus, Prol. Hier. 1, SCh 592, s. 438.

57 Hieronymus, Prol. Ezech. 1, SCh 592, s. 446. 
W wersji hebrajskiej Księgi Hioba rozróżnia z kolei części prozatorskie i poetyckie, pisane zgodnie z zasadami metrum w heksametrze, w którym rozróżnia daktyle i spondeje ${ }^{58}$. Potrafi także zauważyć i docenić akrostychową budowę Lamentacji ${ }^{59}$. Szerzej do literackiej szaty swoich thumaczeń autor nawiązywał $\mathrm{w}$ listach 53 do Paulina z Noli, 57 do Pammachiusza i 70 do Magnusa.

\section{Reminiscencje klasyczne}

Autor do pewnego stopnia odwołuje się do znanych z literatury klasycznej zasad kompozycji przedmów. O przedmowie jako gatunku literackim pisał obszernie Kwintylian w Kształceniu mówcy (IV 1) oraz krócej Cyceron w dziele De inventione (1, 20-22). Kwintylian rozpatrywał tę kwestię w kontekście mów sądowych i politycznych: „Causa prinipii nulla alia est, quam ut auditorem quo sit nobis in ceteris partibus accomodatior, praeperemus. Id fieri tribus maxime rebus inter auctires plurimos constat, si benivolum, attentum, docilem fecerimus" (Inst. IV 1, 5). Podobnie pisał Cyceron: „Exordium est oratio animum auditoris idonee comparans ad reliquam dictionem: quod eveniet, si eum benivolum, attentum, docilem confecerit" (De inv. 1, 20). Zatem celem przedmowy jest zdobycie życzliwości odbiorcy, jego uwagi i otwartości na pouczenie.

Nie zachowały się teoretyczne opracowania literackie z zestawem wskazówek do pisania przedmów do dzieł z gatunku dydaktycznych czy epickich, zachowały się natomiast dwie wskazówki dotyczące przedmów do dzieł historycznych ${ }^{60}$. Przedmowy Hieronima ze względu na ich polemiczny ferwor dają się po części rozpatrywać w kluczu wypowiedzi „sądowych", ze względu zaś na to, jakim księgom towarzyszą, zaliczylibyśmy je do dydaktycznych ${ }^{61}$.

Hieronim w większości swoich przedmów stara się zyskać u odbiorców życzliwość, uwagę i otwartość na pouczenie, gdyż podstawową sprawą do obronienia jest jego nowe thumaczenie ksiąg biblijnych. To ono właśnie, Hieronimowe dzieło translatorskie, jest głównym tematem przedmów, ponieważ było ono gwałtownie atakowane przez współcze-

58 Hieronymus, Prol. Iob (hebr.), 3 SCh 592, s. 398.

59 Hieronymus, Prol. Hier. 2, SCh 592, s. 440.

60 Dla literatury starożytnej w języku łacińskim, por. Rhetores latini minores, red. K. Halm, Lipsiae 1863, s. 588.

61 Por. Stade, Hieronymus in prooemiis, s. 42. 
snych. Zaskakujący jest przy tym fakt, że z przedmów niewiele się dowiadujemy o samych księgach biblijnych. Co więcej, główne przesłanie zbawcze Biblii jest poruszane tylko marginalnie w przedmowach. Nie ma tu apologii Biblii, tylko apologia Wulgaty. Z tego powodu większość przedmów mogłaby z małymi modyfikacjami poprzedzać dowolną księgę biblijną. Wyjątkiem są przedmowy do Ksiąg Kronik (wersja na podstawie Heksapli), Izajasza, Jeremiasza i Proroków Mniejszych, które zawierają informacje czy to o treści księgi, czy to o odpowiednim proroku ${ }^{62}$.

Hieronim był wielkim wielbicielem literatury klasycznej i literackiego języka łacińskiego. Mimo że jako mnich chciał zapomnieć o tym pogańskim dziedzictwie, często się do niego odnosił, co ma swoje echo także w przedmowach. Znajdujemy w nich zarówno nieco dosłownych cytatów z wielkich mistrzów rzymskich, jak i krótkie wzmianki na ich temat ${ }^{63}$. Strydończyk cytuje Wergiliusza, zarówno Georgiki, jak i Eneidę. Cytat $\mathrm{z}$ tego pierwszego dzieła podaje w specyficznym kontekście. W przedmowie do Księgi Daniela wspomina, jak z trudem uczył się języka chaldejskiego (aramajskiego), i wtedy to jego żydowski nauczyciel powtarzał mu w swoim języku (hebrajskim lub aramajskim) słowa Wergiliusza: „Labor omnia vicit improbus" ('zaciekła zdobywa wszystko praca') ${ }^{64}$. Cytat z tego poety rzymskiego pojawia się także w przedmowie do Księgi Ezdrasza. Hieronim, gorąco polemizując $\mathrm{z}$ wrogami swego dzieła translatorskiego, ich działania porównuje do syczenia żmii oraz do kłamliwego Greka Synona (,victorque Sinon incendia iactet” - 'Synon pożar szerzy') ${ }^{65}$, przez którego Trojanie wprowadzili drewnianego konia do swego miasta. Wobec agresywnych działań przeciwników on, Hieronim, i tak nie zamilknie. Wergiliuszowe słowa „dum spiritus hoc regit artus” ('póki duch kieruje [mymi] członkami' $)^{66}$ zostały zastosowane przy składaniu obietnicy przetłumaczenia ksiąg prorockich. Wergiliusz został też wspomniany w innym

62 Por. Schild, Abendländische, s. 41.

63 Por. Stade, Hieronymus in prooemiis, s. 95-97.

64 Por. Vergilius, Georgicon I, 145-146, ed. R.A.B. Mynors, Bibliotheca Oxoniensis, Oxonii 1969, s. 33, tł. A.L. Czerny, Wergiliusz, Georgiki, Warszawa 1956, s. 24. Hieronim cytuje to sformułowanie w: Hieronymus, Prol. Daniel 2, SCh 592, s. 454.

65 Vergilius, Aeneis 2, 329, w: Vergilius, Opera, ed. R.A.B. Mynors, Bibliotheca Oxoniensis, Oxonii 1970, s. 137, tł. T. Karyłowski, Wergilusz, Eneida, Warszawa 2004, s. 55. Wyraz ,victorque” nie został przetłumaczony. Cytat znajduje się w: Hieronymus, Prol. Ezrae 3, SCh 592, s. 366.

66 Hieronymus, Prol. Josue 3, SCh 592, s. 340. Por. Wergiliusz, Aeneis 4, 336, ed. R.A.B. Mynors, s. 186 (tł. na polski własne; Karyłowski ma: „,póki duch mój nie opuści ciała", Wergilusz, Eneida, s. 117). 
kontekście w przedmowie do Ksiąg Kronik (na podstawie Septuaginty), Zdaniem Hieronima podobnie jak czytelnik pierwszej księgi Eneidy lepiej ją rozumie, jeśli sam żeglował z Troady na Sycylię a potem do ujścia Tybru, tak czytelnik Pisma Świętego lepiej je zrozumie, gdy odwiedzi Judeę ${ }^{67}$. Nie znajdujemy tu cytatu ani nawet parafrazy, a jedynie reminiscencję.

Cytat z Horacego pojawia się raz w przedmowie do Księgi Psalmów, przetłumaczonej z języka hebrajskiego. Hieronim cytuje właściwie powiedzenie czy przysłowie znane w wersji polskiej w formie „,nosić drzewo do lasu”, które Horacy w Satyrach podaje w formie „In silvam non ligna feras insanius" ('mniej nierozsądnie wieźć do lasu drewno') ${ }^{68}$. U Hieronima forma ta jest nieco zmieniona: „In silvam ne ligna feras” ("nie nieś drzew do lasu' $)^{69}$. Owym lasem jest świat języka greckiego, a samo wyrażenie ma oddać pokorę Strydończyka wobec wiedzy biblijnej Greków. Ten jeden cytat zaczerpnięty jest z klasyków w analogicznym kontekście, w jakim występuje w tekście źródłowym. W Satyrze (Gawędzie) X w tomie pierwszym Horacy wspomina, jak został zganiony przez Kwirynusa we śnie za „bazgranie wierszy grecką mową”, której najwidoczniej nie znał wystarczająco dobrze, by w niej tworzyć dzieła literackie.

Reminiscencja jednocześnie z Horacego i Cycerona została wykorzystana na początku przedmowy do Księgi Izajasza: grandi fenore liberati, czyli 'uwolnieni od wielkiego długu'70, przy czym u obu autorów klasycznych chodzi o rzeczywisty dług pieniężny, a u Hieronima - o zobowiązania translatorskie. Raz w przedmowach cytowana jest Salustiusza Wojna $z$ Jugurta: „Frustra autem niti neque aliud fatigando nisi odium quaerere extremae dementiae est" ${ }^{\text {"71 }}$. Słowa te, nacechowane goryczą, brzmiałyby po polsku: 'Podejmowanie starań na próżno i szukanie sobie poprzez podej-

67 Por. Hieronymus, Prol. Paralipom. 1, SCh 592, s. 340. Por. Vergilius, Aeneis I, 13-14, ed. R.A.B. Mynors, s. 103, Wergiliusz, Eneida, s. 4.

68 Por. Horatius, Sermones I 10, 34, w: Horatius, Opera, ed. E.C. Wickham H.W. Garrod, Bibliotheca Oxoniana, Oxonii 1963, s. 164, tł. J. Sękowski, Kwintus Horacjusz Flakkus, Dzieła wszystkie, t. 2, red. O. Jurewicz, Warszawa 1988, s. 118.

69 Hieronymus, Prol. Ps. (hebr.), 3, SCh 592, s. 420 (tł. własne).

70 Hieronymus, Prol. Iosue 1, SCh 592, s. 314. Por. Horatius, Epodae II 4: ,solutus omni faenore", w: Horatius, Opera, ed. E.C. Wickham - H.W. Garrod, Bibliotheca Oxoniana, Oxonii 1963, s. 112, Horacjusz, Dzieła wszystkie, t. 1, s. 384, 386; Cicero, Pro Flacco 51: „[...] pecuniam adulescentulo grandi faenore, fiducia tamen accepta, occupavisti”, w: Cicero, Orationes, ed. A.C. Clark, Bibliotheca Oxoniana, Oxonii [1909].

71 Sallustius, Bellum Iugurthinum 3, 4, w: Sallustius, Catilina, Iughurta, Fragmenta ampliora, ed. A. Kurfess, Bibliotheca Teubneriana, Lipsiae 1957, s. 54; u Hieronima: Hieronymus, Prol. Ezrae 1, SCh 59, s. 360 - redaktor nie zidentyfikowała tego cytatu. 
mowane trudy wyłącznie nienawiści jest największą głupotą'. Autor żalił się nimi Rzymianom Domnionowi i Rogacjonowi na ataki ze strony jego przeciwników.

Z literatury klasycznej greckiej w przedmowach użyto raz odniesienia do „Odysei” Homera: „nos ad patriam festinantes mortiferos Sirenarum cantus surda debeamus aure transire" 72 ("my, spiesząc do ojczyzny, winniśmy głuchym uchem ominąc śmiercionośny śpiew Syren'), co stanowi odwołanie do XII księgi wspomnianego dzieła. Hieronim musi z równą stanowczością poświęcić się obiecanemu dziełu przełożenia ksiąg prorockich, co żeglujący Trojanie samej czynności wiosłowania, bez wsłuchiwania się w piękny śpiew Syren. Mnich z Betlejem czyni również aluzję do na legendarnego wydarzenia $\mathrm{z}$ historii rzymskiej, przytoczonego przez Tytusa Liwiusza, chce mianowicie włożyć rękę do ognia w obronie swoich tłumaczeń, jak niegdyś Mucjusz Scewola przed królem etruskim ${ }^{73}$.

Wpływy literatury klasycznej (pogańskiej) nie ograniczają się w przedmowach wyłącznie do cytatów, parafraz i reminiscencji do konkretnych autorów. Słynni mówcy antyczni, Demostenes i Cyceron, są ponadto dla Hieronima wzorem w rozdysponowaniu na karcie trudnego do zrozumienia tekstu prorockiego per cola et commata (w odróżnieniu od scriptura continua) ${ }^{74}$.

Wpływy klasyczne można zauważyć również w elementach formalnych, z jakich komponowano przedmowy. Co ciekawe, w starożytności nie poświęcono szczególnej uwagi tym elementom w teoretycznych zasadach sztuki retorycznej czy oratorskiej. Ponad sto lat temu niemiecki badacz Georg Engel zajął się problematyką przedmów z okresu starożytnego od strony teoretycznej ${ }^{75}$. Z wymienionych przezeń dziewięciu elementów formalnych znajdujemy u Hieronima przynajmniej pięć:

- locus causae: wskazanie powodu, dla którego autor podjął się napisania danego dzieła;

- locus dedicationis: dedykowanie dzieła;

72 Hieronymus, Prol. Iosue 3, SCh 592, s. 320. Odnośny fragment u Homera: Homerus, Odyssea XII, 158-180, red. M.L. West, Bibliotheca Teubneriana, Berlin 2017, s. 260, tł. L. Siemieński, Homer, Odyseja, Warszawa 1959, s. 180-181.

73 Hieronymus, Prol. Esaia 3, SCh 592, s. 434. Odnośny fragment u Liwiusza: Ab urbe condita II 12.

74 Hieronymus, Prol. Esaia 1, SCh 592, s. 432. Por. Van Liere, An introduction, s. 42.

75 G. Engel, De antiquorum epicorum didacticorum historicorum prooemiis. Dissertatio inauguralis quam auctoritate et consensu amplissimi philosophorum ian Academia Philippina Marpurgensi ordinis ad summos in philosophia honores rite capssendos scripsit Georgius Engel Moenofrancofurtensis Borussus, Marpurgi Cattorum 1910. 
- locus commendationis: wskazanie walorów dzieła, dla których warto po nie sięgnąć;

- locus scriptoris de ipso loquentis: słowo autora o sobie i obrona jego dzieła przed zarzutami;

- invocatio numinum: wezwanie Boga na pomoc ${ }^{76}$.

Opracowanie wskazanych elementów formalnych w poszczególnych przedmowach Hieronima winno być przedmiotem osobnego studium.

\section{Podsumowanie}

Pierwszą kwestią, podjętą w niniejszym artykule, było ustalenie liczby Hieronimowych przedmów do ksiąg biblijnych. Zostało to uczynione poprzez zestawienie i omówienie listy znajdującej się w SCh 592 z wcześniejszym studium Stummera (1928) i edycją krytyczną Wulgaty WeberaGrysona (1969, 2007). SCh posiada dwadzieścia trzy przedmowy (oraz List Euzebiusza do Karpiana), z których dwu nie uznaje za Hieronimowe; wspomniane wydanie Wulgaty - dwadzieścia (brak w niej przedmów do tłumaczeń na podstawie tekstu greckiego Ksiąg: Paralipomenon, Hioba i Salomonowych); Stummer wylicza dwadzieścia jeden plus cztery wyimki z dzieła $O$ znakomitych mężach. Drugim zagadnieniem, omawianym w artykule, był krąg adresatów poszczególnych przedmów, którzy zwykle uprzednio prosili o przekład konkretnej księgi lub grupy ksiąg. Chodzi o grupę dziewięciu lub dziesięciu osób, w której poza papieżem Damazym byli dwaj biskupi, nadto mnisi i pobożne rzymskie niewiasty. Wstępne studium zawartości przedmów ujawniło z kolei, że brakuje w nich tych elementów, których w tego typu kompozycjach czytelnik się spodziewa. Zamiast nich poznajemy głównie apologię pracy translatorskiej św. Hieronima, ale również ocenę literacką wybranych ksiąg biblijnych. Ostatnią kwestią poruszoną w tym opracowaniu są odniesienia do klasycznej literatury greckiej i rzymskiej, które nie sprowadzają się

76 Engel wylicza jeszcze dodatkowe cztery elementy niespotykane w przedmowach Hieronima do ksiąg biblijnych: locus indicationis: zapowiedź tematu, któremu poświęcone jest dane dzieło; locus dispositionis: objaśnienie podziału dzieła i rozmieszczenia treści; locus recordationis: stosowane w dłuższych dziełach, przed kolejnymi księgami, przypomnienie o treści poprzedniej księgi (ksiąg); laudatio historiae universa, czyli pochwała ogólna historii jako takiej, była ona stosowana wyłącznie w przedmowach do dzieł historycznych. Zob. Engel, De antiquorum epicorum didacticorum historicorum prooemiis, s. 7, 42 . 
wyłącznie do cytatów z wielkich dzieł i aluzji do nich, ale obejmują także formalne elementy kompozycyjne. Ten ostatni temat pozostał nierozwinięty i pozostawiony jako postulat badawczy.

\section{Prologues of Saint Jerome to the Biblical Books in the Vulgate - Introductory Questions}

(summary)

In 2017 a special volume containing the critical edition of the prologues of saint Jerome to the biblical books has been published in the Sources Chrétiennes series (No. 592). Based on this edition and on older studies this paper presents a list of the prologues written by st. Jerome and a list of the addressees of the translation into Latin of the individual biblical books. Furthermore the article raises a question of the content of the prologues and their links to the ancient, pagan literature. Consequently the paper highlights the texts composed by Jerome directly as prologues, permits to know the milieu of his spiritual friends and also to get inside the efforts of the oeuvre of translation undertaken by Jerome.

Keywords St. Jerome; Vulgate; biblical translations; prologues to the biblical books

\section{Świętego Hieronima przedmowy do ksiąg biblijnych w Wulgacie - zagadnienia wstępne}

(streszczenie)

W roku 2017 opublikowano w serii Sources Chrétiennes (nr 592) tom zawierający edycję krytyczną przedmów do ksiąg biblijnych autorstwa św. Hieronima. W oparciu o to wydanie, a także starsze opracowania, w niniejszym artykule została przedłożona lista przedmów autorstwa Hieronima i lista odbiorców łacińskich tłumaczeń poszczególnych ksiąg. Ponadto w artykule zostaje podjęta kwestia merytorycznej treści przedmów i odniesień do literatury antycznej. Dzięki tym analizom można wyróżnić teksty, które Strydonita faktycznie pisał jako przedmowy, poznać krąg jego duchowych przyjaciół, a ponadto dowiedzieć się o trudach pracy translatorskiej i zarzutach przeciwników dzieła Hieronimowych thumaczeń.

Słowa kluczowe: Św. Hieronim; Wulgata; tłumaczenia biblijne; przedmowy do ksiąg biblijnych 


\section{Bibliografia}

\section{Źródła}

Biblia sacra iuxta vulgatam versionem, red. R. Weber - R. Gryson, Stuttgart 2007.

Biblia sacra, Gniezno, Archiwum Archidiecezjalne, sygn. BK Ms 142.

Cicero, Pro Flacco, w: Cicero, Orationes, ed. A.C. Clark, Bibliotheca Oxoniensis, Oxonii [1909].

Hieronymus, Epistulae, pars 1, red. I. Hilberg, CSEL 54, Vindobonae - Lipsiae 1910, tł. J. Czuj - M. Ożóg, Hieronim ze Strydonu, Listy, t. 1-2, ŹMT 54-55, Kraków 2010.

Hieronymus - Gennadius, De viris inlustribus, red. C.A. Bernoulli, Freiburg im Breisgau - Lepzig 1895, tł. W. Szołdrski, Św Hieronim, O znakomitych mężach, Eteria, Pielgrzymka do miejsc świętych, PSP 6, Warszawa 1970.

Homerus, Odyssea, red. M.L. West, Bibliotheca Teubneriana 2026, Berlin 2017, tł. L. Siemieński, Homer, Odyseja, Wrocław 1959.

Horatius, Epodae; w: Horatius, Opera, red. E.C. Wickham - H.W. Garrod, Bibliotheca Oxoniana, Oxonii 1963, Kwintus Horacjusz Flakkus, Dzieła wszystkie, t. 2: Gawędy, listy, sztuka poetycka, red. O. Jurewicz, Warszawa 1988.

Jérôme, Préfaces aux livres de la Bible, red. A. Canellis, SCh 592, Paris 2017.

Quintilianus, Institutionis oratorie libri XII, pars prior, red. L. Radermacher - V. Buchheit, Bibliotheca Teubneriana, Lipsiae 1959.

Rhetores latini minores, red. K. Halm, Lipsiae 1863.

Sallustius, Bellum Iugurthinum, w: Sallustius, Catilina, Iughurta, Fragmenta ampliora, red. A. Kurfess, Bibliotheca Teubneriana, Lipsiae 1957.

Vergilius, Aeneis, w: Vergilius, Opera, red. R.A.B. Mynors, Bibliotheca Oxoniana, Oxonii 1970, tł. T. Karyłowski, Wergiliusz, Eneida, Warszawa 1981.

Vergilius, Georgicon, w: Vergilius, Opera, ed. R.A.B. Mynors, Bibliotheca Oxoniana, Oxonii 1969, tł. A.L. Czerny, Wergiliusz, Georgiki, Warszawa 1956.

\section{Opracowania}

Brown-Tkacz C., Labor tam utilis. The creation of the Vulgate, „Vigiliae Christianae” 50 (1996) s. 42-72.

Canellis A., Introduction, w: Jérôme, Préfaces aux livres de la Bible, red. A. Canellis, SCh 592, Paris 2017, s. 53-247.

Cimosa M., Guida allo studio della Bibbia latina. Dalla Vetus Latina, alla Vulgata, alla Nova Vulgata, t. 1, Roma 2008.

Dekkers E., Clavis Patrum Latinorum, Turnhout 1995.

Engel G., De antiquorum epicorum didacticorum historicorum prooemiis. Dissertatio inauguralis quam auctoritate et consensu amplissimi philosophorum in Academia Philippina Marpurgensi ordinis ad summos in philosophia honores rite capessen- 
dos scripsit Georgius Engel Moenofrancofurtensis Borussus, Marpurgi Cattorum, [Marburg] 1910.

Gräfenhain R., De more libros dedicandi apud scriptores Graecos et Romans obvio, Marpurgi Cattorum, [Marburg] 1892.

Houghton H., The Latin New Testament: A Guide to its Early History, Texts, and Manuscripts, Oxford 2016.

Majewski M., Jak przekłady zmieniają Biblię. O ttumaczeniu Pisma Świętego raz jeszcze, Kraków 2019.

Norden E., Die antike Kunstprosa, wyd. 10, Leipzig 1995.

Repertorium Biblicum Medii Aevi, t. 1: Initia biblica, apocrypha, prologi, red. F. Stegmüller - K. Reinhardt, Madryt 1981.

Steinmann J., Hieronymus. Ausleger der Bibel. Weg und Werk eines Kirchenvaters, Leipzig [1973].

Schild M.E., Abendländische Bibelvorreden bis zur Lutherbibel, Heidelberg 1970.

Stade W., Hieronymus in prooemiis quid tractaverit et quos auctores quasque leges rhetoricas secutus sit, Rostochii 1925.

Stummer F., Einführung in die lateinische Bibel, Paderborn 1928.

Van Liere F., An introduction to the medieval Bible, New York 2014.

Zampa P., I santi del Friuli, Pradamano 1930. 